\title{
Karakteristik dan Komposisi Karkas Pada Sapi Krui di Kabupaten Pesisir Barat Provinsi Lampung
}

\author{
B. F. Dewantara, M. D. I. Hamdani, Sulastri, dan K. Adhianto* \\ Departmen of Animal Husbandry Faculty of Agriculture Lampung University
}

\begin{abstract}
ABSTRAK
Penelitian ini bertujuan untuk mengetahui karakteristik dan komposisi karkas Sapi Krui di Kabupaten Pesisir Barat Lampung. Penelitian ini dilaksanakan pada Juni-Juli 2016 di Kabupaten Pesisir Barat Lampung mengenai karakteristik yang meliputi bobot potong, persentase karkas, persentase kulit, dan persentase lemak kidney pelpic heart serta komposisi karkas yang meliputi persentase lemak, persentase tulang, dan persentase daging. Sampel yang digunakan sebanyak 108 ekor, jantan berjumlah 18 ekor dan betina 90 ekor. Hasil penelitian di analisis dengan metode deskriptif. Rata-rata bobot potong Sapi Krui jantan 220,28+16,93 kg dan sapi betina 180,26+9,66 kg, persentase karkas Sapi Krui jantan 48,09+2,23\% dan sapi betina $44,47+4,37 \%$, persentase kulit Sapi Krui jantan $6,47+0,66 \%$ dan sapi betina 7,02+0,41\%, persentase lemak kidney pelpic heart Sapi Krui jantan $0,86+0,11 \%$ dan sapi betina 0,92+0,15\%, persentase lemak Sapi Krui jantan 5,58+0,72\% dan sapi betina 5,28+0,57\%, persentase tulang Sapi Krui jantan 13,66+1,01\% dan sapi betina 13,44+0,86\%, persentase daging Sapi Krui jantan $37,30+1,71 \%$ dan sapi betina $33,68+4,13 \%$.
\end{abstract}

Kata kunci: Karakteristik karkas, Komposisi karkas, Sapi Krui

\section{Characteristic and Carcass Composition of Krui Cattle in Pesisir Barat Regency, The Province of Lampung}

\begin{abstract}
The purpose of the resarch was knowing characteristic and composition carcass of krui cattle on Pesisir Barat Region, Lampung Province. This reserch was hold on June-July 2016, abaout characteristic like body weigh, carcass percentage, skin percentage, and kidney pelpic heart fat percentage, and composition carcass like fat percentage, bone percentage, meat percentage, meat bone ratio, and meat fat ratio. The result of reserch refers to descriptive analisisc on average from body weigh on male krui cattle is $220,28 \mathrm{~kg}$ and female krui cattle $180,26 \mathrm{~kg}$, carcass percentage on male krui cattle is $48,09 \%$ and female krui cattle $44,47 \%$, skin precentage on male krui cattle $6,47 \%$ and famale krui cattle 7,02\%, percentage of kidney pelpic heart fat on male krui cattle is $0.86 \%$ and famele $0,92 \%$, fat percentege of male krui cattle is 5,58\% and female 5,28\%, bone precentage of male krui cattle is $13,66 \%$ and famale $13,44 \%$, maet precentage of male krui cattle is $34,43 \%$ and famale krui cattle $31,01 \%$
\end{abstract}

Keywords: Carcass characteristic, Carcass compotition, Krui cattle

\section{PENDAHULUAN}

Indonesia merupakan daerah yang memiliki jenis sapi lokal yang telah menjadi pencitraan sebagai sapi asli Indonesia. Menurut (Pane, 1986) sapi yang tergolong sapi lokal Indonesia antara lain sapi Bali, sapi Madura, dan sapi Sumatera. Sapi Lokal memiliki banyak keuntungan apabila kita nilai dari segi ketahanan fisik dan minimnya biaya pemeliharaan. Namun jika dinilai dari cepat dalam berkembang biaknya sapi lokal Indonesia belum mampu menyamai jenis sapi impor.

Provinsi Lampung merupakan daerah yang memiliki potensi untuk pengembangan usaha di bidang peternakan yang cukup tinggi. Hal ini dinilai dari jumlah populasi ternak potong di Provinsi Lampung yang cukup tinggi. Menurut data Statistik Provinsi Lampung pada tahun 2015 ternak sapi potong mencapai 653.537 ekor yang tersebar di seluruh kabupaten yang ada di Provinsi Lampung. Tingginya angka populasi tersebut dipengaruhi oleh ketersedian

\footnotetext{
*Penulis Korespondensi: K. Adhianto

Alamat: Gedong Meneng, Rajabasa, Bandar Lampung 35141

E-mail: kusuma adhianto@fp.unila.ac.id.
}

pakan dan lahan yang memadai.

Kabupaten Pesisir Barat merupakan kabupaten termuda di provinsi lampung. Kabupaten ini berdiri sejak tahun 2012. Kabupaten Pesisir Barat merupakan daerah agraris yang ditunjukkan dengan mata pencaharian pokok penduduknya disektor pertanian, peternakan, perkebunan, dan Perikanan. Secara geografis wilayah Kabupaten Pesisir Barat berbatasan langsung dengan Provinsi Bengkulu, Kabupaten Lampung Barat, Kabupaten Tanggamus, dan Samudra Hindia.

Sapi yang ada di Kabupaten Pesisir Barat merupakan jenis sapi lokal yang telah mengalami perkembang biakan secara alami di daerah tersebut.

Masyarakat Kabupaten Pesisir Barat menyebut sapi yang ada dengan sebutan sapi Krui atau "Jawi Peghia" yang artinya sapi kecil. Sapi yang ada di Kabupaten Pesisir Barat tergolong dalam jenis sapi yang memiliki postur tubuh yang kecil.

Masyarakat Pesisir Barat terbiasa mengkonsumsi sapi baik dalam acara adat ataupun kehidupan seharihari. Sampai saat ini kebutuhan daging masyarakat Pesisir Barat masih dapat dipenuhi oleh suplai lokal yang berarti dari hasil pemotongan Sapi Krui. Karakteristik karkas dipengaruhi oleh beberapafaktor 
antara lain jenis kelamin, bobot tubuh, umur, dan bangsa serta performa karkas dipengaruhi bobot ternak saat pemotongan.

Berdasarkan uraian di atas maka perlu dilakukan penelitian untuk mengetahui tingkat performa Sapi Krui yang dapat memenuhi kebutuhan daging di Kabupaten Pesisir Barat Lampung. Tingkat performa tersebut dapat di ukur dengan mengetahui karakteristik karkas dan komposisi karkas, pada Sapi Krui di kabupaten Pesisir Barat Lampung tersebut.

\section{MATERI DAN METODE}

\section{Materi}

Alat yang digunakan dalam penelitian ini adalah kuisioner yang dirancang khusus untuk mempermudah dalam pengambilan data penelitian, alat tulis untuk melakukan pencatatan, kamera, dan timbangan sapi kapasitas $2000 \mathrm{~kg}$, timbangan gantung kapasitas 150 $\mathrm{kg}$, timbangan gantung kapasitas $20 \mathrm{~kg}$, dan timbangan duduk dengan kapasitas $10 \mathrm{~kg}$.

Bahan yang digunakan sebagai obyek dalam penelitian ini adalah Sapi Krui yang dipotong di Tempat Potong Hewan (TPH) di Kabupaten Pesisir Barat Lampung. Sapi Krui yang digunakan sebanyak 108 ekor terdiri dari jantan 18 ekor dan betina 90 ekor.

\section{Metode}

Pengambilan data karkas dimulai dengan melakukan pemotongan terhadap ternak sapi yang telah dipuasakan terlebih dahulu. Adapun prosedur pemotongan yang telah dilakukan di TPH (Tempat Potong Hewan) yang ada di Kabupaten Pesisir Barat antara lain: (1) Tahapan awal adalah dengan mengikat ternak pada tempat pengikat khusus yang telah dicor agar kokoh menahan gerakan sapi. Setelah sapi terikat dilakukan perobohan dengan mengikat salah satu kaki belakang dan penarikan bagian ekor, (2) Setelah sapi tertidur dilakukan pengikatan 4 bagian kaki agar tidak meronta pada saat pelaksanaan penyembelihan, (3) Persiapan selanjutnya adalah memberikan celah antara leher dan lantai dengan meletakan balok pada bagian leher bawah ternak untuk seanjutnya dilakukan penyembelihan, (4) Penyembelihan dilakukan dengan memotong vena jugularis dan arteri aortis serta memotong saluran pencernaan dan saluran pernapasan. Setelah darah sudah tidak mengalir kembali ikatan pada sapi dilepaskan dan bagian bagian kaki kiri dan lengan depan kiri digantung agar mempermudahkan dalam proses pengulitan, (5) Pelepasan kulit dilakukan dengan memisahkan kulit yang menempel pada daging dengan mengiris selaput yang menjadi pembatas antara daging dan kulit. Kulit dilepaskan dengan cara membuat irisan sepanjang garis tengah dada dan abdomen (Soeparno, 1994). Irisan kedua dilakukan sepanjang medial kaki memotong irisan pertama. Kulit dilepaskan dari awal ventral ke arah punggung tubuh, (6) Eviserasi, adalah proses pengeluaran organ viseral (organ dalam tubuh) dari tubuh ternak. Proses ini harus dilakukan secara hati-hati agar tidak terjadi kebocoran terhadap organ pencernaan, jika terjadi maka daging dapat terkontaminasi oleh mikroba dalam organ pencernaan. Tulang pelvis dibelah dan saluran pencernaan beserta organ dalam dikeluarkan (Soeparno, 1994), (7) Lemak pada rongga perut, dada, serta pelvic dikumpulkan dan ditimbang dalam satuan gram dan menghasilkan bobot lemak kidney pelvic heart (KPH) (Herman, 1993). Perbandingan bobot lemak KPH dengan bobot karkas akan menghasilkan data persentase lemak KPH (Obst et al., 1980; Rudiono et al., 1994), dan (8) Wholesale $\mathrm{cu}$, merupakan proses pemotongan karkas menjadi 4 bagian. Proses ini dilakukan dengan tujuan mempermudah penjual dalam proses penjualan di pasar tradisional. Selain itu proses ini meninggalkan bagian tulang pelvis, rusuk kiri dan kanan, tulang leher, serta tulang punggung. Sehingga dalam proses ini dapat dilakukan penimbangan karkas dan sebagian bagian tulang.

Proses pemotongan menghasilkan karkas bersih setelah darah, kulit, kepala, kaki, dan organ dalam dilepaskan (Edey, 1983). Penimbangan karkas dilakukan dengan menggunakan timbangan gantung kapasitas $150 \mathrm{~kg}$, menghasilkan bobot karkas dalam satuan kilogram (Soeparno, 1994). Perbandingan bobot karkas dengan bobot potong menghasilkan data persentase karkas (Obst et al., 1980).

\section{Peubah yang Diamati}

Peubah yang diamati meliputi bobot potong, persentase karkas, kulit, lemak kidney pelvic heart, lemak tubuh, tulang dan daging.

Bobot potong. Bobot potong diukur sebelum ternak dipotong dengan cara menimbang ternak hidup dengan menggunakan timbangan dengan kapasitas timbang $1000 \mathrm{Kg}$.

Persentase Karkas. Persentase karkas diperoleh dari bobot karkas dibagi dengan bobot potong sapi dikalikan dengan 100\%. Perhitungan Tersebut dapat dilakukan dengan rumus:

\section{$\%$ Karkas $=($ Bobot Karkas $) /($ Bobot Potong $) \times 100$}

Persentase kulit. Persentase kulit dihitung dengan menimbang bobot kulit yang telah di lepaskan dari karkas sapi yang telah terlebih dahulu di potong. Perhitungan Tersebut dapat dilakukan dengan rumus:

$\%$ Kulit $=($ Bobot Kulit $) /($ Bobot Potong $) \times 100$

Persentase lemak kidney pelvic heart. Pengukuran persentase lemak kidney pelvic heart dilakukan dengan cara menimbang lemak pada rongga perut, dada, serta pelvic. Penimbangan dilakukan dengan Bosch dalam satuan gram dan menghasilkan lemak KPH. Pembandingan bobot lemak KPH dengan bobot karkas akan menghasilkan data persentase lemak KPH. Perhitungan Tersebut dapat dilakukan dengan rumus: 
$\%$ Lemak kidney pelvic heart $=($ Bobot kidney pelvic heart)/(Bobot Potong) x 100

Persentase lemak. Menghitung persentase lemak perlu dilakukan untuk mengetahui kualitas karkas. Perhitungan persentase lemak dilakukan dengan mengukur tebal beberapa bagian tubuh ternak Perhitungan Tersebut dapat dilakukan dengan rumus:

$\%$ Lemak $=($ Bobot lemak $) /($ Bobot Karkas $) \times 100$

Persentase tulang. Persentase tulang diukur dengan cara mengitung bobot tulang tubuh yang telah di pisahkan dari daging. Perhitungan bobot tulang perlu dilakukan guna mendapatkan persentase daging dalam seekor ternak sapi. Perhitungan Tersebut dapat dilakukan dengan rumus:

$\%$ Tulang $=($ Bobot Tulang $) /($ Bobot Karkas $) \times 100$

Persentase daging. Setelah menghitung persentase tulang maka dapat kita ketahui persentase daging. Menghitung persentase daging dilakukan dengan cara menimbang bagian yang termasuk kategori daging. Perhitungan Tersebut dapat dilakukan dengan rumus:

$\%$ Daging $=($ Bobot Daging $) /($ Bobot Karkas $) \times 100$

Imbangan daging tulang (meat bone ratio). Dalam menghitung imbangan daging tulang (Meat Bone Ratio) di lakukan setelah mendapatkan bobot tulang dan bobot daging secara keseluruhan. Dengan data bobot tersebut maka perbandingan antara banyaknya tulang dan daging dalam satu ekor ternak sapi dapat terukur. Perhitungan Tersebut dapat dilakukan dengan rumus:

Rasio Daging dan Tulang $=(\%$ Daging $) /(\%$ Tulang $)$

Imbangan daging lemak (meat fat ratio). Perhitungan imbangan daging lemak (Meat Fat Ratio) di lakukan dengan mengetahui bobot daging dan bobot lemak dalam tubuh ternak. Setelah kedua data tersebut didapatkan maka dapat dihitung perbandingan jumlah daging dan lemak. Imbangan ini sangat menentukan kualitas daging dan proporsi tubuh ternak yang di potong. Perhitungan Tersebut dapat dilakukan dengan rumus:

Rasio Daging dan Lemak $=(\%$ Daging $) /(\%$ Lemak $)$

\section{Analisis Data}

Data bobot Potong, persentase karkas, persentase kulit persentase lemak kidney pelvic heart, persentase lemak, persentase tulang, dan persentase daging dihitung berdasarkan bobot potong. Untuk selanjutnya di analisis secara deskriptif (Sunyoto, 2016).

\section{HASIL DAN PEMBAHASAN}

\section{Karakteristik Karkas Sapi Krui}

Karakteristik karkas Sapi Krui dapat diketahui dengan bobot potong, persentase karkas, persentase kulit, dan persentase lemak kidney pelvic heart. Hasil peneitian menunjukan perbedaan yang cukup jelas terhadap perbedaan karakteristik jantan dan karakteristik betina. Perbandingan tersebut dapat dilihat pada tabel 1 dan tabel 2 .

Bobot potong. Bobot potong merupakan salah satu parameter yang digunakan untuk mengukur karakteristik karkas (Rudiono, 2000). Bobot potong dan bobot karkas merupakan salah satu variable yang dapat mempengaruhi persentase karkas. Hasil penelitian mendapatkan rata-rata bobot potong untuk ternak Sapi Krui betina mencapai $180,26+9,66 \mathrm{~kg}$ nilai terendah $160,00 \mathrm{~kg}$ dan nilai tertinggi mencapai $206,00 \mathrm{~kg}$. Rata-rata bobot potong sapi jantan mencapai $220,28+16,93 \mathrm{~kg}$ nilai terendah $189,00 \mathrm{~kg}$ dan nilai tertinggi mencapai $245,00 \mathrm{~kg}$. Jika dibandingkan, bobot potong sapi jantan jauh lebih tinggi karena postur tubuh Sapi Krui pejantan memang jauh lebih besar dibandingkan dengan Sapi Krui betina.

Sapi dapat dikategorikan sebagai sapi yang memiliki produktivitas tinggi apabila memiliki persentase karkas yang tinggi. Ismail et al., (2014) menyatakan bahwa peningkatan komponen karkas akan mengakibatkan kenaikan bobot potong. Jika di bandingkan dengan jenis sapi lain bobot potong Sapi Krui memang cukup rendah, namun hal tersebut dapat dinyatakan wajar karena karakteristik tubuh Sapi Krui yang tergolong sangat kecil di kelasnya sebagai sapi lokal Indonesia.

Pernyataan Soeparno (1994) memiliki kesamaan dengan pernyataan Ismail et al, (2014) dimana bobot potong yang tinggi akan menghasilkan produksi karkas yang tinggi pula. Dalam kaitanya dengan umur, pertambahan umur ternak yang sejalan dengan pertambahan bobot hidup maka bobot karkas akan semakin tinggi. Dalam sampel jantan yang diambil saat penelitian bobot potong sapi cukup tinggi dikarenakan Sapi Krui jantan yang digunakan

Tabel 1. Bobot potong, persentase karkas, persentase kulit dan persentase lemak KPH Sapi Krui jantan

\begin{tabular}{lccccc}
\hline \multicolumn{1}{c}{ Peubah } & $\begin{array}{c}\text { Jumlah data } \\
(\mathrm{N})\end{array}$ & $\begin{array}{c}\text { Nilai } \\
\text { Maksimum }\end{array}$ & $\begin{array}{c}\text { Nilai } \\
\text { Minimum }\end{array}$ & Rata-rata & $\begin{array}{c}\text { Standar } \\
\text { Deviasi }\end{array}$ \\
\hline Bobot Potong (Kg) & 18 & 245,00 & 189,00 & 220,28 & 16,93 \\
Karkas (\%) & 18 & 52,73 & 44,54 & 48,09 & 2,23 \\
Kulit (\%) & 18 & 7,87 & 5,74 & 6,47 & 0,66 \\
Lemak Kidney Pelpic & 18 & 1,07 & 0,11 & 0,86 & 0,11
\end{tabular}

Heart $(\%)$ 
Tabel 2. Bobot potong, persentase karkas, persentase kulit dan persentase lemak KPH Sapi Krui betina

\begin{tabular}{lccccc}
\hline \multicolumn{1}{c}{ Peubah } & $\begin{array}{c}\text { Jumlah data } \\
(\mathrm{N})\end{array}$ & Nilai Maksimum & Nilai Minimum & Rata-rata & Standar Deviasi \\
\hline Bobot potong (Kg) & 90 & 206,00 & 160,00 & 180,26 & 9,66 \\
Karkas (\%) & 90 & 55,67 & 37,60 & 44,47 & 4,39 \\
Kulit (\%) & 90 & 8,06 & 6,17 & 7,02 & 0,41 \\
Lemak kidney pelpic heart & 90 & 1,35 & 0,64 & 0,92 & 0,15 \\
$(\%)$ & & & & \\
\hline
\end{tabular}

merupakan sapi jantan yang memiliki umur $>6$ tahun yang dapat dilihat pada perubahan gigi seri depan mengalami poel secara keseluruhan dan sudah mengalami pengeroposan.

Persentase karkas. Perbandingan antara berat karkas dengan bobot potong ternak dapat menghasilkan persentase karkas. Hasil penelitian ratarata bobot persentase karkas Sapi Krui betina $44,47+4,39 \%$, terendah $37,60 \%$ dan nilai tertinggi $55,67 \%$ dari rata-rata bobot $180,26+9,66 \mathrm{~kg}$. Persentase karkas Sapi Krui jantan 48,09+2,23\%, nilai terendah $44,54 \%$ dan nilai tertinggi $52,7 \overline{3} \%$ dari ratarata bobot potong sebesar $220,28+16,93 \mathrm{~kg}$. Nilai ini lebih rendah jika dibandingkan dengan pernyataan Saladin (1983) menyatakan bahwa persentase karkas Sapi Krui mencapai 50,6\%. Tentu menjadi perbandingan persentase yang sangat jauh di bandingkan ternak Sapi Krui yang terpotong di Kabupaten Pesisir Barat.

Persentase karkas dipengaruhi oleh umur, jenis kelamin, dan bangsa (Philips, 2001). Menurut Rudiono (2000) perbandingan antara bobot karkas dengan bobot potong akan menghasilkan nilai persentase karkas. Persentase karkas bertambah dengan meningkatnya bobot potong, maka persentase nonkarkas dan isi saluran pencernaan akan berkurang dengan meningkatnya bobot potong (Herman,1983). Brahmantiyo (1996) menjelaskan bahwa sapi yang memiliki bobot badan berbeda tetapi persentase karkasnya sama maka hal tersebut dikarenakan adanya perbedaan bobot nonkarkas yang dihasilkan.

Ada beberapa faktor yang mempengaruhi persentase karkas, yang utama yaitu konformasi tubuh dan derajat kegemukan. Ternak yang gemuk, persentase karkasnya tinggi dan umumnya berbentuk tebal seperti balok. Sedangkan ternak yang langsing, badan panjang, leher panjang dan berbentuk segitiga seperti sapi perah, persentase karkasnya umumnya rendah (1994).

Persentase kulit. Hasil penelitian persentase kulit pada Sapi Krui jantan sebesar 6,47+0,66\%, nilai tertinggi $7,87 \%$ dan nilai terendah $5,74 \%$. Pada Sapi
Krui betina rata-rata persentase kulit adalah $7,02+0,41 \%$, nilai tertinggi sebesar $8,06 \%$ dan terendah $6,71 \%$. Sapi Krui betina memang memiliki postur tubuh yang lebih kecil dibandingkan Sapi Krui jantan namun Sapi Krui betina memiliki persentase kulit yang lebih tinggi dibandingkan dengan Sapi Krui jantan.

Banyak faktor yang mempengaruhi perbedaan bobot pada kulit Sapi Krui jantan dan betina diantaranya; umur, tebel lemak subkutan, kerapihan dalam menguliti, serta jenis kelamin. Menurut Soeparno (1994) kulit yang besar dan juga tebal akan berpengaruh terhadap persentase karkas.

Ternak Sapi Krui yang dipelihara secara lepas dan dipanen dalam fase umur yang tidak muda tentu dapat mempengaruhi bobot kulit. Lemak pada kulit yang sudah terbentuk dengan sempurna dan ketebalan kulit karna selalu difungsikan terhadap suhu lingkungan pun dapat menjadi faktor yang berpengaruh terhadap ketebalan kulit.

Persentase lemak kidney pelvic heart. Lemak kidney pelvic heart (KPH) merupakan lemak yang terdapat pada rongga pelvis dan di area rongga dalam tubuh ternak. Pengukuran lemak ini dimaksudkan untuk mengetahui kadar lemak dalam organ ternak menjadi faktor koreksi akan kondisi kesehatan ternak Sapi Krui. Hasil penelitian menunjukan rata-rata KPH Sapi Krui betina sebesar $0,92+0,15 \%$, nilai terendah $0,64 \%$ dan nilai tertinggi $1,35 \%$. Rata-rata lemak KPH Sapi Krui jantan $0,86+0,11 \%$, nilai terendah $0,11 \%$ dan nilai tertinggi $1,07 \%$.

Faktor yang dapat menjadi pertimbangan dalam mengkoreksi nilai KPH adalah iklim di Kabupaten Pesisir Barat dan manajemen pemeliharaan ternak itu sendiri. Energi dalam tubuh ternak dicukupi dari sumber pakan alam yang seadanya dan itu difungsikan untuk memproduksi energi untuk kehidupan pokok sehingga kemungkinan ternak untuk memiliki nilai lemak KPH yang tinggi juga sulit.

Penurunan bobot lemak KPH dapat terjadi karena beberapa alasan antara lain 1), hormon testosteron ternyata mampu meningkatkan

Tabel 3. Persentase lemak, persentase tulang, dan persentase daging Sapi Krui jantan berdasarkan bobot potong rata-rata

\begin{tabular}{lccccc}
\hline \hline Peubah & Jumlah data (N) & Nilai Maksimum & Nilai Minimum & Rata-rata & Standar Deviasi \\
\hline Lemak (\%) & 18 & 7,66 & 4,78 & 5,58 & 0,72 \\
Tulang (\%) & 18 & 15,85 & 12,24 & 13,66 & 1,01 \\
Daging (\%) & 18 & 40,00 & 34,03 & 37,30 & 1,71 \\
\hline
\end{tabular}


Tabel 4. Persentase lemak, persentase tulang, dan persentase daging Sapi Krui betina berdasarkan bobot potong rata-rata

\begin{tabular}{lccccc}
\hline \hline \multirow{2}{*}{ Peubah } & Jumlah data (N) & Nilai Maksimum & $\begin{array}{c}\text { Nilai } \\
\text { Minimum }\end{array}$ & Rata-rata & Standar Deviasi \\
\hline Lemak (\%) & 90 & 7,15 & 4,27 & 5,28 & 0,57 \\
Tulang (\%) & 90 & 15,54 & 10,55 & 13,44 & 0,86 \\
Daging (\%) & 90 & 43,78 & 26,95 & 33,68 & 4,13 \\
\hline
\end{tabular}

responsibilitas chatecholamine dan pada saat yang sama meningkatkan aktifitas lipase lipoprotein Marim et al. (1992), 2), karena adanya efek aditif antara hormon pertumbuhan dengan testosteron, yakni dengan cara meningkatkan kepadatan reseptor $\beta$ andrenergic Yang et al. (1995), 3) pada taraf hormon testosteron berlebih, pengeluaran hormon pertumbuhan menjadi tertahan (Vestergaard et al., 1995) karena adanya mekanisme feed back negatif dan pada saat yang bersamaan terjadi proses protein turn over yang membutuhkan energi (Pringle et al., 1993).

Sinergi dari kedua peristiwa ini menyebabkan cadangan lemak tubuh diubah menjadi energi. Secara fisik, akumulasi penggunaan cadangan lemak sebagai energi terlihat pada ukuran bobot lemak KPH yang menurun.

\section{Komposisi Karkas Sapi Krui}

Komposisi karkas Sapi Krui dapat diketahui dengan persentase lemak, persentase tulang, dan persentase daging. Hasil penelitian menunjukan perbedaan yang cukup signifikan terhadap perbedaan komposisi jantan dan komposisi betina.

Perbedaan tersebut tentu jelas karena perbedaan jenis kelamin akan mempengaruhi dari segi jumlah ataupun persentase berdasarkan bobot potongnya selain itu komposisi karkas sapi jantan jauh lebih tinggi di bandingkan sapi betina. Perbandingan tersebut dapat dilihat pada Tabel 3 dan Tabel 4.

Persentase lemak. Perbandingan bobot lemak dengan bobot potong akan menghasilkan persentase lemak tubuh Sapi Krui. Hasil penelitian menunjukan lemak pada Sapi Krui betina sebesar 5,28\%, nilai terendah 4,27\% dan nilai tertinggi 7,15\% dari rata-rata bobot potong sebesar $180,26+9,66 \mathrm{~kg}$. Lemak pada Sapi Krui jantan sebesar 5,58\% nilai terendah $44,78 \%$ dan tertinggi $7,66 \%$ dengan simpangan baku $0,72 \%$ dari bobot rata-rata sebesar $220,28+16,93 \mathrm{~kg}$.

Peranan lemak adalah sebagai cadangan energi untuk menghadapi saat-saat sulit pakan. Hewan dari daerah tropis memiliki lemak yang lebih sedikit dalam tubuhnya (Berg dan Butterfield, 1976). Jaringan lemak dibentuk dalam jumlah sedikit pada saat lahir kemudian meningkat pada fase tertentu terjadi peningkatan laju pertumbuhan lemak sehingga digolongkan kedalam kondisi dewasa lambat hal ini yang dapat dinyatakan terjadi pada Sapi Krui di Kabupaten Pesisir Barat Lampung.

Menurut Thompson et al., (1979) dalam Elmansyah (1996) lemak merupakan komponen karkas yang dewasa lambat sehingga proporsi bobot lemak akan meningkat seiring dengan meningkatnya bobot tubuh dan umur ternak. Burg dan Butterfield (1976) menyatakan bahwa lemak mempunyai pengaruh besar pada proporsi urat daging karkas karena jumlah dan penyebarannya nyata mempengaruhi nilai karkas.

Persentase tulang. Perbandingan antara bobot tubuh dengan bobot tulang akan mengahasilkan persentase tulang pengukuran tulang dilakukan dengan tujuan agar mengetahui komposisi tulang dari satu ekor ternak terpotong. Tulang juga dapat menjadi acuan dalam menentukan memprediksi konsumsi mineral yang dikonsumsi oleh ternak tersebut. Hasil penelitian menunjukan rata-rata persentase tulang dari ternak Sapi Krui jantan 13,44\% nilai terendah 12,24\% dan nilai tertinggi $15,85 \%$ dari rata-rata bobot potong $220.28+16,93 \mathrm{~kg}$

Rata-rata persentase tulang Sapi Krui betina $13,44 \%$, nilai terendah $10,55 \%$ dan nilai tertinggi $15,54 \%$ dari bobot potong $180,26+9,66 \mathrm{~kg}$.Tulang merupakan salah satu komponen tubuh yang berfungsi sebagai penyangga tubuh, tempat melekatnya daging, dan untuk melindungi bagian-bagian tubuh yang lunak. Berg dan ĐButterfield (1976) menyatakan bahwa tulang adalah komponen karkas yang paling dini. Selanjutnya Thompson et.al., (1979) dalam Elmansyah (1996) menyatakan bahwa tulang digolongkan sebagai komponen yang dewasa paling dini. Pertumbuhan tulang mempunyai peranan penting dalam pertumbuhan ternak, sebab pertumbuhan dan perkembangan tulang akan menentukan ukuran ternak dan bobot potong ternak (Cole dan Garret, 1980 dalam Elmansyah, 1996).

Persentase daging. Data persentase daging dieroleh dari hasil perbandingan bobot karkas yang telah dikurangi bobot tulang dengan bobot potong ternak Sapi Krui. Bobot daging merupakan hal yang sangat penting dalam mengetahui performa seekor ternak, dimana bobot daging dapat menjadi kunci utama dalam menentukan indeks perdagingan. Hasil penelitian persentase daging pada ternak Sapi Krui jantan $37,30 \%$ nilai terendahnya $34,03 \%$ dan nilai tertinggi $40,00 \%$ dari rata-rata bobot potong $220.28+16,93 \mathrm{~kg}$. Sapi Krui betina 33,68\%, nilai terendah $26,95 \%$ dan nilai tertinggi $43,78 \%$ dari bobot potong $180,26+9,66 \mathrm{~kg}$.

Brahmantyo (1996) menjelaskan nilai perdagingan sangat di pengaruhi oleh bobot badan, bobot karkas, lemak yang menutupi, konformasi tubuh serta bangsa. Fumlah serabut otot juga sangat menentukan nilai perdagingan dan berdasarkan Kauffman (2001) jumlah serabut otot sangat 
ditentukan oleh faktor genetik, fase pertumbuhan, jenis kelamin dan jumlah aktivitas fisik ternak. Brahmantyo (1996) menambahkan bahwa diameter serabut otot bervariasi tergantung jenis dan bangsa sapi, perkembangan otot setelah lahir, ukuran tubuh, umur, pakan, aktivitas, dan bangsa.

\section{KESIMPULAN}

Berdasarkan hasil penelitian dapat disimpulkan bahwa rata-rata bobot potong Sapi Krui jantan $220,28+16,93 \mathrm{~kg}$ dan sapi betina $180,26+9,66 \mathrm{~kg}$, persentase karkas Sapi Krui jantan 48,09+2,23\% dan Sapi Krui betina $44,47 \pm 4,39 \%$, persentase kulit Sapi Krui jantan $6,47+0,66 \%$ dan sapi betina 7,02+0,41\%, persentase lemak kidney pelpic heart Sapi Krui jantan $0,86 \pm 0,11 \%$ dan sapi betina $0,92 \pm 0,15 \%$, persentse lemak Sapi Krui jantan $5,58+0,72 \%$ dan sapi betina $5,28+0,57 \%$, persentase tulang Sapi Krui jantan $13,66+1,01 \%$ dan sapi betina $13,44+0,86 \%$, pesentase daging Sapi Krui jantan 37,30+1,71\% dan sapi betina $33,68+4,13 \%$.

\section{DAFTAR PUSTAKA}

Berg R. T., and R. M. Butterfield. 1976. New Conceptsof Cattle Growth. Sydney. University Press. Sydney

Brahmantiyo, B., Y. C. Raharjo $\overline{\bar{z}}$ dan T. Murtisari. 1996. Karakterisasi produktivitas kelinci di lapang sebagai sumber plasma nutfah ternak Indonesia. Seminar Nasional Teknologi Peternakan dan Veteriner. Fakultas Peternakan Institut Pertanian Bogor

Edey, T. N. 1983. The genetic pool of sheep and goats. In: Tropical Sheep and Goat Production (Edited by Edey. T.N.). Australia University International. Development Program. Canberra.

Elmansyah. 1996. Studi Banding Bobot Karkas, Lemak, Tulang, Daging, Serta Rasio Daging dan Tulang antara Domba Priangan dan Domba Ekor Gemuk. Skripsi. Universitas Lampung. Bandar Lampung

Herman, R. 1983. Budidaya Ternak Ruminasia Kecil. Fakultas Peternakan. Institut Pertanian Bogor, Bogor

Ismail, M., H Nuraini dan R. Priyanto. 2014. Perlemakan pada sapi bali dan sapi madura meningkatkan bobot komponen karkas dan menurunkan persentase komponen nonkarkas Jurnal Veteriner 15(3): 411-421.

Kauffman, R. G. 2001. Meat Composition dalam Hui, Y. H.,Wai-Kit Nip,R. Roger (ed) Meat Science and Applications diedit oleh. Marcel Dekker, Inc. New York

Marin P, S. Holmang, L. Jonsson, L. Sjostrom, H. Kvist, G. Holm, G. Lindstedt, and P. Bjorntorp. 1992. The effects of testosterone treatment on body composition and metabolism in middleaged obese men. International Journal of Obesity and Related Metabolic Disorders : Journal of the International Association for the Study of Obesity 16(12): 991-997.

Obst, J. M., T. D. Chaniago, and T. Boyes 1980. Survey on Sheep and Goats Slaughtered at Bogor, West Java Indonesia. Centre for Animal Research and Development, Bogor

Pane, I. 1986. Pemulia Biakan Ternak Sapi. PT. Gramedia. Jakarta.

Philips, C. J. C. 2001. Priciples of Cattle Production. Bidles Ltd, Guildford and King's Lynn. England

Pringle, T. D., C. R. Calkins, M. Koohmaraie and S. J. Jones. 1993. Effects over time of feeding a betaadrenergic agonist to wether lambs on animal performance, muscle growth, endogenous muscle proteinase activities, and meat tenderness. Journal of Animal Science 1993 71(3): 636-644.

Rudiono, D. I. Harris dan Y. Widodo. 1994. Kualitas karkas kambing lokal pada berbagai umur di Provinsi Lampung. J. Penel. Pengemb. Wilayah Lahan Kering 14: 149.

Rudiono, D. 2000. Pengaruh Hormon Testosteron dan Umur Terhadap Performans Produksi Kambing Kacang Betina. Disertasi. Universitas Padjadjaran. Bandung.

Saladin, R. 1983. Penampilan Sifat-sifat Produksi dan Reproduksi Sapi Lokal Pesisir Selatan di Provinsi Sumatera Barat. Disertasi. Fakultas Pascasarjana Institut Pertanian Bogor.

Soeparno. 1994. Ilmu dan teknologi daging. Edisi kedua. Gadjah Mada University Press, Yogyakarta

Sunyoto, D. 2016. Statistika Deskriptif dan Probabilitas. CAPS (Center for Academic Publising Service). Yogyakarta.

Vestergaard, M., S. Purup, P. Henckel, E. Tonner, D. J. Flint, L. R. Jensen, and K. Sejrsen. 1995. Effects of GH and ovariectomy on performance, serum hormones, IGH Binding proteins, and muscle fibre properties of pre- pubertal Friesian heifers. Journal of Animal Science 73(12): 35743584.

Yang, S., X. Xu, P. Björntorp, S. Edén. 1995. Additive effects of growth hormone and testosterone on lipolysis in adipocytes of hypophysectomized rats. Journal of Endocrinology 147(1): 147-152. 